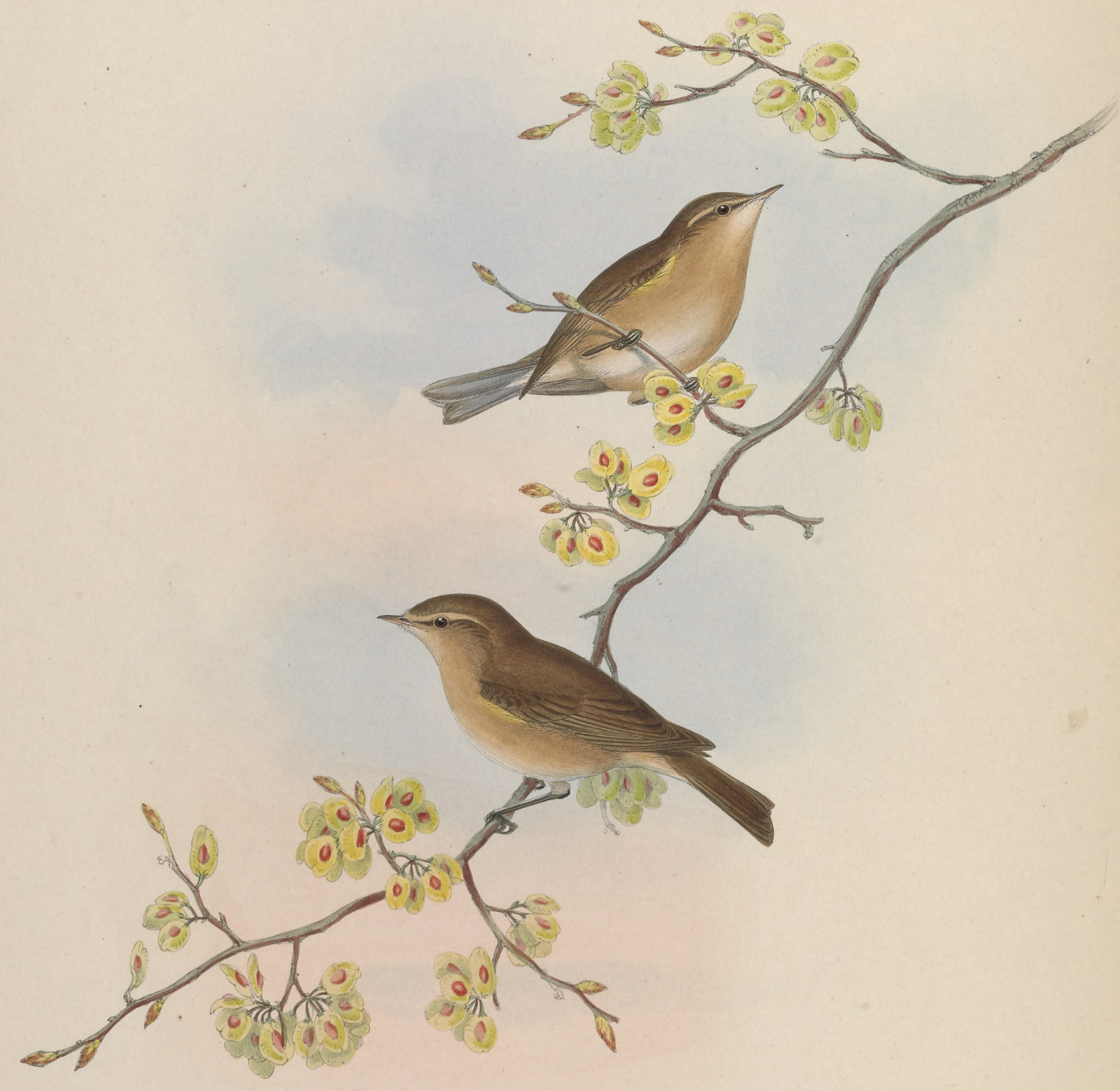




\section{PHYLLOPNEUSTE TRISTIS.}

Phylloscopus tristis, Blyth, Journ. Asiat. Soc. Beng., vol. xii. p. 996, and vol. xvi. p. 591 ; Ann. Nat. Hist., vol. xiii. p. 178 ; Cat. of Birds in Mus. Asiat. Soc. Calcutta, p. 185.-Horsf. and Moore, Cat. of Birds in Mus. East-Ind. Comp., vol. i. p. 336.-Adams in Proc. Zool. Soc., part xxvi. 1858, p. 493, and part xxvii. 1859 , p. 182.-Jerd. Birds of India, vol. ii. p. 190.

Regulus tristis, Gray and Mitch. Gen. of Birds, vol. i. p. 175, Regulus, sp. 8

Abrornis tristis, Bonap. Consp. Gen. Av., tom. i. p. 290, Abrornis, sp. 5.

Sylvia trochilus, Jerd. Madras Journ. of Lit. and Sci., vol. xi. p. 6.

ALL, or nearly all, the members of the genus Phyllopneuste inhabiting India differ from those frequenting Europe and Northern Africa. The present bird, of which four examples are now before me, possesses specific characters which, if closely attended to, will materially assist ornithologists in their investigation of this intricate group of little birds, to which so many trivial names have been applied-Willow-Wrens, LeafWrens, Tree-Wrens, \&c.

The Phyllopneuste tristis is intermediate in size between the Chiff-chaff and Willow-Wren of our island, and differs from both in the brown colouring of the upper surface and the scarcely less deep brown of its ear-coverts, sides of the neck, and flanks; this brown colour also pervades the eye-streak; and there is in fact no trace of yellow over any portion of the body, except on the under surface of the shoulders and on the tips of the axillaries, where, as will be seen on reference to the accompanying Plate, it is perceptible even when the wing is closed.

Since my drawing was made I have observed that Mr. Blyth considers this bird and the Sylvia brevirostris of Strickland, which is a native of the country around Smyrna, to be identical; but on comparison of specimens from Smyrna, I find that they do not agree with the Indian one, and, with all due deference to Mr. Blyth's opinion, I believe that he is in this instance mistaken, and that his name of $P$. tristis should be retained for the Indian bird.

Mr. Blyth says this species is "common in swampy places wherever there is jungle, and diffused generally over India." He "also found it abundant in a mango-tope, near Hooghly, where there was no marshy ground in the immediate vicinity."

Mr. Jerdon obtained a specimen in Southern India, " in a wooded valley along the edge of the Northern range of Ghauts. It is lively and active in its habits, occasionally flying from among the reeds, on which it was perched, and alighting on a stone in the water, whence it made short sallies after insects in the air, or seizing one in the sand of the rivulet."

Dr. Adams states that it is common in the Deccan, Scinde, and North-west Bengal, and tolerably abundant on the lesser ranges in the jungles, and in all wooded situations in Cashmere.

The following is Mr. Jerdon's accurate description of this species :-

"Above uniform dull brown; below albescent; with a faint ruddy tinge on the pale supercilia; the sides of the neck, of the breast, and flanks, axillaries, and fore part of the wing beneath, pure light yellow ; irides brown ; bill blackish yellow beneath and at the gape ; legs brownish black."

The figures are of the natural size. 


\section{$2 \mathrm{BHL}$ Biodiversity Heritage Library}

Gould, John. 1865. "Phyllopneuste tristis [PI. 59]." The Birds of Asia 4(XVII), -https://doi.org/10.5962/p.323438.

View This Item Online: https://www.biodiversitylibrary.org/item/120503

DOI: https://doi.org/10.5962/p.323438

Permalink: https://www.biodiversitylibrary.org/partpdf/323438

\section{Holding Institution}

Smithsonian Libraries

\section{Sponsored by}

Smithsonian Institution Libraries

\section{Copyright \& Reuse}

Copyright Status: Not in copyright

This document was created from content at the Biodiversity Heritage Library, the world's largest open access digital library for biodiversity literature and archives. Visit BHL at https://www.biodiversitylibrary.org. 